VOL. V, FASC. I E 2, P.87.94

\title{
ON ONCHIDELLA INDOLENS (Gould, 1852)
}

(RECEIVED JULY/23/105E)

Eveline and Ernst Marcus

(Caixa Postal 6994, Såo Paulo, Brasil)

Professor A. Remane - Kiel (Germany) working as guest of the Oceanographic Institute, São Paulo (Prof. W. Besnard), at the station of Cananéia (Dr. V.Sadowsky) in 1952, observed certain slugs on the rocks in front of the station. Later (1954) Dr. S.Gerlach - Kiel and we found the same animals at Itanhaém, São Vicente, and Ubatuba. This "lesma da pedra", as it is appropriately called by the people of the coast, is Onchidella indolens (Gould 1852) that was discovered by the United States Exploring Expedition on the Ilha do Pai near Rio de Janeiro.

The Onchidiacea are marine or exceptionally terrestrial euthyneurous Gastropoda with a lung and retractile tentacles bearing eyes on their summit. They hatch from the egg capsules with the external appearance of the adults. Until recently (Thiele 1931, p. 485) they were included in the Pulmonata Stylommatophora. After Fretter's morphological and embryological study (1943) however this classification is no longer possible. The Onchidiacea should be placed with the Opisthobranchia and "regarded as a small twig from the base of the main stem" (Fretter 1943, p. 717) or as an independent Order of the Euthyneura in Boettger's system (1952, p. 267, 286-90) that abandons the conventional Subclasses Opisthobranchia and Pulmonata.

A few weeks agowe sent some morphological remarks on Onchidella indolens and another species, that A. Remane had collected on the Canaries, to the Editor of the "Kieler Meeresforschungen", in the 
12th volume of which they are due to be published. Shortly after Prof. W.Besnard invited us for a stay at the second Station of the Oceanographic Institute, $14 \mathrm{~km}$ west of Ubatuba, where the Head, Dr. E. Nonato, received us with most amiable hospitality.

In the course of 1954 we had with repeated efforts that were often in vain brought together 21 Onchidella indolens. This time we were delighted to see hundreds of these nice slugs on our first look at the boulders and rocks of granite and gneiss around the station at half past six in the morning of july 3,1955 . Also on the following days we found them grazing on the rocks at low tide. At high tide they are hidden.

The greater number of the slugs were $12-20 \mathrm{~mm}$ long, but many were still larger, to a maximum of $30 \mathrm{~mm}$ length when creeping, $15 \mathrm{~mm}$ breadth, and $7 \mathrm{~mm}$ height. Their colour varies independent of age; dark pigmented (Fig. 1) and lighter (Fig. 2) specimens were mingled without relation to the substratum, dark tufts of Phaeophyceae and Cyanophyceae or light stretches of rock. Also the foot varies from pure white over dirty white to grayish brown. We did not observe any colour change that was noted in Onchidium dämelii and O.chameleon (Bretnall 1919, p. 303).

The texture of dry and wet slugs is different. The creeping or browsing, almost dry animals (Fig. 4, 5) are firm and smooth and high, and their perinotal glands are hardly marked. Animals at rest on the dry rock often contract their notum in paramedian lines so that the middle appears somewhat puffy (Fig. 3 ). When they were wetted with sea water (Fig. 7) they flattened and their notal and marginal glands were produced and gave the notum a prickly aspect. The richly developed cutaneous muscles permit the slugs to fold and to wrinkle their notal epidermis. Such an enlargement of the respiratory surface might be biologically significant for the cutaneous respiration under water, while during the aerial phase pulmonary respiration in the damp atmosphere enables active life (Fretter 1943, p. 697-98).

In the first week of july 1955 small slugs (Fig. 6) of about $5 \mathrm{~mm}$ length were rare. From this fact together with Fretter's data for O.celtica (1943, p. 706) one might perhaps conclude that 0 . indolens also laysits eggs in the warm season. Onchidella celtica, the northern limit of which is the extreme south western coasts of England, and Onchidium verruculatum from Japan, Misaki, Sagami Bay (Hirasaka 1922, p. 171) pass through a period of very limited activity in winter (Arey Crozier 1921, p. 450). Such a hibernation does not occur in Onchidella indolens and in O. floridana from the Bermudas and Florida. 


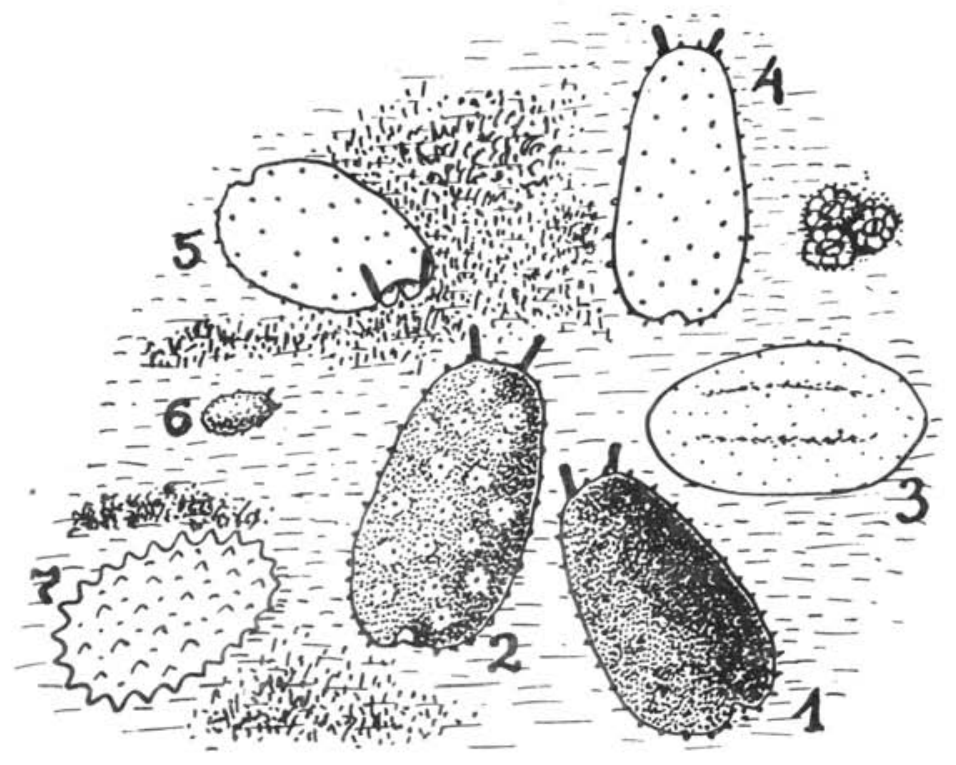

EXPLANATION OF THE FIGURE

1 - Plain slate gray speoimen.

2 - Brownish slug with light aress around the large notal glands.

8 - Resting animal with paramedian oontractions.

4 - Greeping slug.

5 - Grasing slug.

6 - Young specimen.

7 - Animal that has been moistenod with sea water. 
During our observation period in the beginning of july the water at the station was rather turbid and rich in sediments. The bottom seaward to the inhabited stones was partly muddy, and the sediments are probably present all the year round. Therefore the rocks are covered with a fine layer of mud that forms a dense felt with the algae. Remane in a letter called this facies "Steinschlick" and stressed its importance for O.indolens. This layer of mud with Phaeophyceae and Cyanophyceae contains also great quantities of Diatons. The station lies in a deep bay protected against the surf of the open Atlantic by an island with $350 \mathrm{~m}$ high hills (Ilha dos Porcos of older maps, to-day Ilha Anchieta). Sheltered positions are also indicated for other species of Onchidella (Joyeux-Laffuie 1882, p. 236; Arey Crozier 1921, p. 463; Beauchamp 1923 , p. 499; Fretter 1943, p. 685). Nevertheless the rocks a round the station are differently exposed to the force of the waves corresponding to the configuration of the shore line and their seaward or landward position. The development of the mud layer varies likewise. Where it is very thick, there are no 0 .indolens, either because the mud fills their hiding places, or they cannot creep because their mucous trail does not adhere to the smooth and soft ooze. On rocks however, that appear devoid of algae to the eye, we found slugs, so that the occurrence of diatom beds can be inferred.

The browsing slugs (Fig. 5) lift the anterior border of the notum so that one sees the oral lobes grasping an alga that is rasped off and eaten. The mud, the "tangue" of Vaillant (1871; Joyeux-Laffuie 1882, p. 238) is not eaten but taken into the stomach in small quantities together with the food plants. Also chance animals were found in the contents of the alimentary tract: in one large slug there were 10 mites and $2 \mathrm{Littorines.}$

Dark blue Protura that are frequent on the rock exposed by the tide often run over the notum of the slugs without producing any visible reaction. The slugs generally browse in the middle barnacle zone. Previously we found them in the zone of Sabellariids of the genus Phragmatopoma. As for O.celtica the necessities of protection and moisture (Beauchamp 1923, p. 499) may be offered by different biotopes (Prenant 1932, p. 84). Also at the Oceanographic Station of Ubatuba O.indolens occurs lower down among Tetraclita and higher up between oysters. Ligyda exotica is generally found on other stones than 0 .indolens; these scurrying Isopods have a much greater vertical range.

Several times we saw 0 .indolens on boulders that are separated from the rocks by sand at low tide and by water at high tide. 
That shows that they are occasionally washed off from their rock and thrown onto another stone. We have seen some out on the rock that were splashed by single higher waves of the receding tide. Such slugs may be dislodged from their substratum. We did not find $O$. indolens easy to lift from the stones. O.celtica and 0 . floridana are said to be feebly attached to the rock (Joyeux-Laffuie 1882, p. 237; Arey Crozier 1921, p. 451, 458). The loosened slugs curl up like sea cradles, and it takes a rather long time, about 1 minute at $20^{\circ} \mathrm{C}$, till they uncurl.

Some of the rocks had small tide pools of $7-20 \mathrm{~cm}$ diameter and $3-6 \mathrm{~cm}$ depth. If the slugs came into these on their walk or were put in to them, they either crept out or remained squeezed into a cleft or hidden under a prominence. When they leave their crevice or return to it they often $g \circ$ in single file. This is not due to furrows on the surface or special smoothness of the tone but to the often very narrow entrance of the hiding place. Outside the slugs show pronounced gregariousness. They have well developed eyes with lenses and groups of sensory cells, probably chemo- and tangoreceptors, on their tentacles and oral lobes. Possibly the mucous track helps them to find their hiding place. In Queensland "the surroundings of the nest of Onchidium verruculatum in pieces of dead coral showed a worn appearance, as though the slugs had wandered to and from their cavities" (Allan 1950, p. 366). At a distance of $8-10 \mathrm{~cm}$ from their crack the animals scatter and graze like a flock of sheep on hill, often in groups of two or three, but also singly on the periphery. The 20-100 slugs that have emerged from one cleft remain in an area of about $1,5 \mathrm{~m}$ around the hiding place. They can eventyally mix with the inhabitants of another nest. A group of about 30 slugs that we had marked with a spot of fuchsine on the back dispersed later on and went to different holes. The homing habits of Onchidella floridana were studied by Arey Crozier (1921) and are excellently summarized in the "Bronn" by Hoffmann (1928, p. 1210-1212).

The hiding places are in long and probably deep crevices, in which one cannot see the siugs except at the moment of their emerging. They are also inhabited by crabs that do not seen to interfere with the slugs. Some of the latter that were seen on atones without any clefts and surrounded by sand may have hidden in empty shells of Tetraclita. Such was also observed on the Bermudas for a biologically different, only 2, 5 ma long (Arey \& Crosier 1919, p. 163 , note 4 ), species that creeps about when covered by the sea and shelters within dead barnacle ahells and the like during low tide (Arey \& Crozier 1921, p. 446). Under the stones of $20-30 \mathrm{~cm}$ 
diameter lying beside inhabited boulders we did not find any slugs. Eight specimens that we collected in november 1954 under several stones had possibly been swept from their original lodgings. Certain Onchidiacea, f.ex., Watsoniella lesliei (Stearns) occur normally under stones (Steinbeck \& Ricketts 1941, p. 220; 545).

Generalizing one can say: in the region inhabited by 0 .indolens the slugs are outside their nest from one and a half hour before to two hours after low tide. We assume that the oxygen entering with the air into the cavity when the tide goes out stimulates the slugs. The hiding places are dark or almost dark, and in them there will only be diatoms washed in by the waves as available food. Therefore the alarmed animals, if they are hungry, will leave their cleft. According to the different depths of the holes they will take more or less time to emerge. While they creep out they will be chiefly directed by optic impressions; outside they probably depend upon their statocysts and wander mostly farther up the rock to their pasture-grounds. On their return they glide more continuously. The slugs from one hole may already be coming home when those from another are just leaving theirs. Probably differences in hunger cause irregularities of going out. Joyeux-Laffuie (1882, p. 238) has observed slugs remaining in a nest from which others had emerged. The different depth of the cavities, their height in relation to the tide, and their position towards the wind are further causes for varying exits of the slugs. For example the animals from a higher cleft in a farther seaward stone may be out, while those from a landward deeper cave are not yet visible. If these appear later, they would be neither satiated nor dried when the tide turns and reaches them. Under such instances they may be washed in to the water, where they can save themselves if they happen to come under stones, as certain other slugs that we had found last year.

When it is windy or rains, only single, probably very hungry slugs emerge, generally not the largest specimens, and stay where they are protected against the wind. As wind dries them, and rain is a hypotonic liquid, the negative response to wind and rain are biologically significant. After Joyeux-Laffuie (1882, p. 246) the cuicle of 0 . celtica is dissolved by fresh water. Negative anemotaxis is reported for O.celtica, O.floridana, and Onchidium verruculatum (Fretter 1943, p. 685; Arey \& Crozier 1921, p. 450). We observed the negative influence of wind alone, without rain, but had no opportunity to watch the behaviour of the animals on rainy, calm days.

With Joyeux-Laffuie (1882, p. 237-8) we think that drying is 
the main reason for return, be it the drying of the wall of the lung cavity or that of the sole or of the pasture. The slugs do not a void sun nor react to the sudden shadow of the observer. But if they have been exposed to plain sun for a time, f.ex., a middle-sized slug for 20 minutes, it moves rapidly away from the sun. Larger slugs, that have a relatively smaller evaporating surface, bear exposure to sun for a longer time. With other species it is different, Watsoniella lesliei, f.ex., must be "strong and tough for they were in the high rocks, fairly dry and exposed to the killing sun" (Steinbeck \& Ricketts 1941, p. 226).

\section{RES U M O}

A "lesma da pedra", Onchidella Indolena (Gould, 1852), descrita da Ilha do Pai, perto do Rio de Janeiro, e, em 1952-54, verificada em várias looalidades da costa de São Paulo, foi encontrada, em julho de 1955, às centenas, nas rochas situadas defronte à "Base Norte" do Instituto Oceanogrófico, $14 \mathrm{~km}$ a o oeste de Ubatuba. Essas lesmas comen Diatomf́cess e outras algas crescidas ns película de sedimentos que recobre as pedras. Sôbre estas deslizam durante a vasante, fors dágua, respirando ar atmosférico por meio da sua cavidade pulmonar. Antes de voltar a mart, as lesms escondem-se em fendas das rochss, onde permanecem durante a enchente. Debaixo dóguas, a respiragâo 6 cutânea. Im dias vontosos nấ saem dos seus ninhos.

Sisteàtioamente, não são mais incluidas nos PulmonataStylommatophors, mas consideradas cono pertencentes a uma Ordem especial, seja dos Opisthobranohia ou seja, pars quen preferir suprinir esta Subclssse dos Gastropoda, dos Euthyneurs.

\section{REF ERENCE S}

ALLAN, J.

1950. Australian Shells, oto. XIX-470 p., 112 f., 44 pl. Melbourne (Goorgian House).

AREY, L.B. \& CROZIER, W.J.

1918. The sensory responses of Chiton. Journ. Exper.Zool., Vol. 29, p. 167-260. Philadolphia, Pa.

1921. On the natural history of Onchidium. Ibid. Vol. $82, p \cdot 443-502$. Phil adel phia, Pa.

BEAUCHAMP, P. de

1923. Études de biononie interootidale. Les fles de R6 et d'Yeu. Arch.Zoo1.Expér.Góntr., Vol. 61 (1922-23), faso. 3 (1923), p. 455-520, pl. 17-24. Paris. 


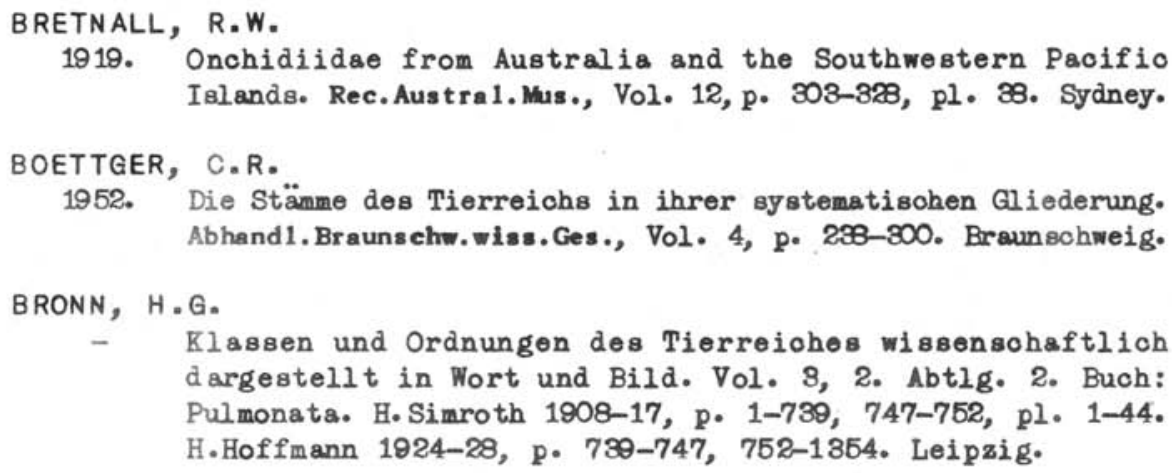

1852. U.S. Expl. Bxped. Vol. 12, Mollusca \& Shells. XV-510 p. Atlas (1856) $52 \mathrm{pl}$. Boston, Mass. \& Philadelphia, Pa.

HIRASAKA, K.

1922. On the structure of the dorsal eyes of Onchidium, eto. Annot.Zool.Japon., Vol. 10, n. 17, p. 171-181, 1 pl. Tokyo.

JOYEUX-LAFFUIE, J.

1882. Organisation et développement de l'Onoidie. Arch.Zoo1.Exp. Gón. śr. 1, Vol. 10, p. 225-383, pl. 14-22. Paris.

PRENANT, $M$.

1932. F́tudes de bionomie intercotidale, eto. Trav.stat.Biol.Roscoff, f asc. 10, p. 37-103. Paris.

STEINBECK, J. \& RICKETTS, E.F.

1941. Sea of Cortez. X-598 p., 40 pl., 2 charts. New York (Viking Press).

THIELE, J.

1931. Handbuch der systematisohen Weichtierkunde. Vol. 1, VI-778 p. Jena (G. Fisoher). 